\title{
The pattern of globalization and some implications for the pursuit of social goals
}

Working Paper No. 55

Gerry Rodgers

Policy Integration Department

International Labour Office

Geneva

February 2005 
Copyright (C) International Labour Organization 2005

Publications of the International Labour Office enjoy copyright under Protocol 2 of the Universal Copyright Convention. Nevertheless, short excerpts from them may be reproduced without authorization, on condition that the source is indicated. For rights of reproduction or translation, application should be made to the Publications Bureau (Rights and Permissions), International Labour Office, CH-1211 Geneva 22, Switzerland. The International Labour Office welcomes such applications.

Libraries, institutions and other users registered in the United Kingdom with the Copyright Licensing Agency, 90 Tottenham Court Road, London W1T 4LP [Fax: (+44) (0)20 7631 5500; email: cla@cla.co.uk], in the United States with the Copyright Clearance Center, 222 Rosewood Drive, Danvers, MA 01923 [Fax: (+1) (978) 750 4470; email: info@copyright.com] or in other countries with associated Reproduction Rights Organizations, may make photocopies in accordance with the licences issued to them for this purpose.

ISBN 92-2-117734-3 (printed version)

ISBN 92-2-117735-1 (Web version).

First published 2005

Cover:

The designations employed in ILO publications, which are in conformity with United Nations practice, and the presentation of material therein do not imply the expression of any opinion whatsoever on the part of the International Labour Office concerning the legal status of any country, area or territory or of its authorities, or concerning the delimitation of its frontiers.

The responsibility for opinions expressed in signed articles, studies and other contributions rests solely with their authors, and publication does not constitute an endorsement by the International Labour Office of the opinions expressed in them.

Reference to names of firms and commercial products and processes does not imply their endorsement by the International Labour Office, and any failure to mention a particular firm, commercial product or process is not a sign of disapproval.

ILO publications can be obtained through major booksellers or ILO local offices in many countries, or direct from ILO Publications, International Labour Office, CH-1211 Geneva 22, Switzerland. Catalogues or lists of new publications are available free of charge from the above address, or by email: pubvente@ilo.org

Visit our website: www.ilo.org/publns 


\section{The pattern of globalization and some implications for the pursuit of social goals}

\section{Contents}

Preface

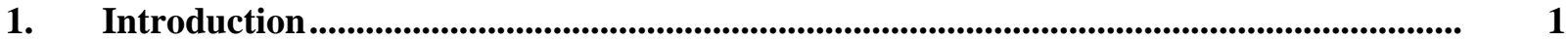

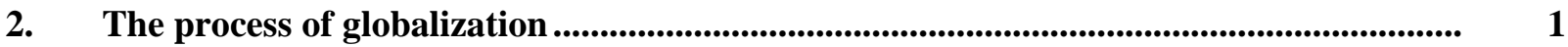

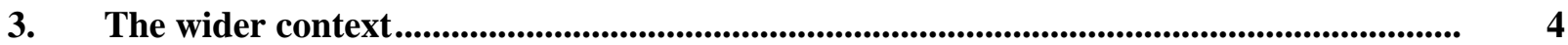

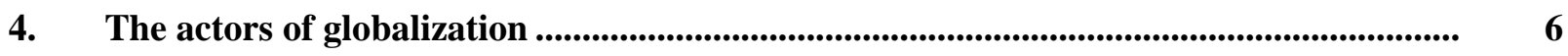

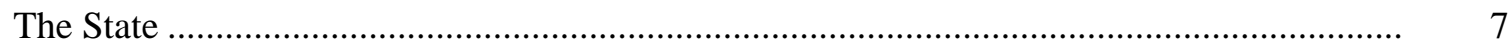

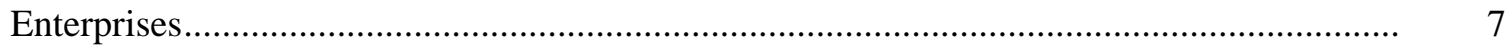

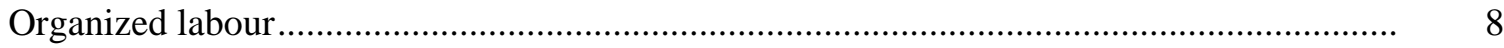

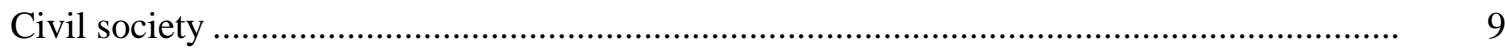

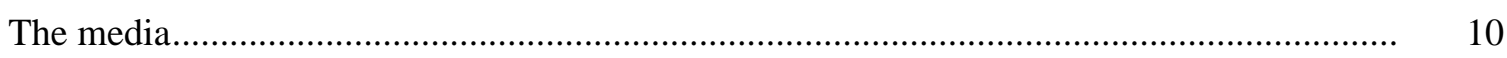

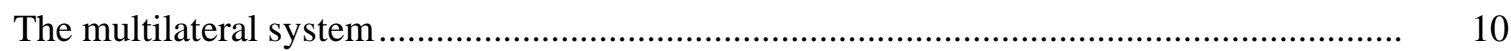

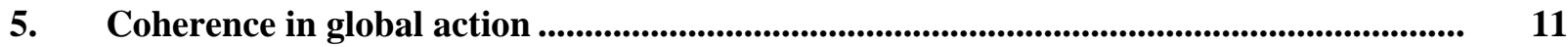

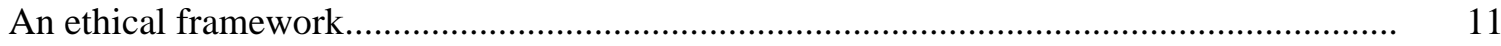

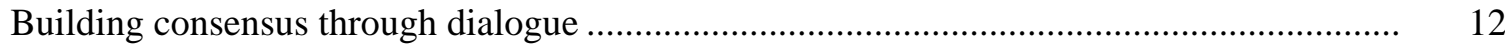

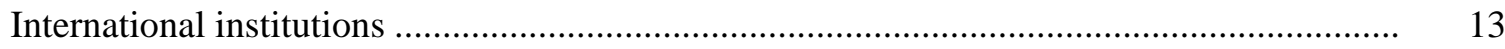

6. The globalization policy agenda and development .................................................... 13

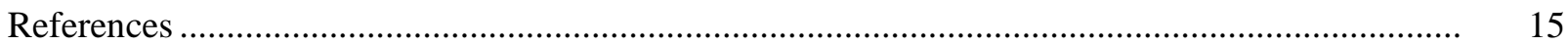





\title{
Preface
}

In this Working Paper, Gerry Rodgers, Director of the International Institute of Labour Studies, reminds us that, "The shape and impact of globalization are not predetermined."

As former Technical Director for the World Commission on the Social Dimension of Globalization, the author picks up key themes of the Commission's 2004 report and draws on its preparatory work.

He stresses the challenges posed by the disparity between countries in terms of levels of development and between individuals in terms of levels of income. After reviewing the main characteristics of globalization, he examines the roles of various actors: the State, enterprises, organized labour, civil society, the media and the multilateral system.

The Working Paper then highlights how ethical frameworks, consensus through dialogue and international institutions can serve the purpose of a fair globalization through greater coherence in global action. Working Papers are intended to stimulate debate. Comments on them are welcome at integration@ilo.org.

\author{
Anne Trebilcock \\ Director ad interim \\ Policy Integration Department \\ International Labour Office
}


"We believe that the central challenge we face today is to ensure that globalization becomes a positive force for all the world's people."

(UN Millennium Declaration, 2000). 



\section{Introduction ${ }^{1}$}

Most people would agree that globalization brings opportunities and benefits. But few would agree that those opportunities and benefits are fairly distributed. Globalization is widely seen as unbalanced and unequal, a process that benefits only a minority of people and of countries, leaves many excluded and brings real disadvantage to some.

Of course, most of today's critical social problems - poverty and exclusion, disease and illiteracy, insecurity and unemployment, lack of voice and lack of respect for basic rights predated the present phase of globalization, and have other immediate causes, so at worst globalization has exacerbated them. But globalization, precisely because it creates new opportunities, has the potential to be part of the solution. The persistence of these problems in a globalized world is a fundamental failing of the present pattern of globalization.

This paper explores some of the ways in which globalization might better serve social goals, drawing on the work of the World Commission on the Social Dimension of Globalization (2004) As its name implies, the World Commission argued that it is essential to pay more attention to the social dimension of globalization.

The word "social" covers a lot of ground. Education and health are social domains, as are political rights and collective organization. The social dimension of globalization includes issues of social inclusion and exclusion, inequality and discrimination, culture and identity, rights and responsibilities. These, as much as economic goals, are everyday concerns of people and priorities of the societies in which they live.

Many aspects of globalization have both economic and social dimensions. That is particularly true of work. Work is about production and income. But it is also about identity and social integration. This gives work and employment a critical position in any effort to simultaneously achieve economic and social goals. If globalization is to provide benefits for all, it must be the source of a sufficient volume of productive employment. At the same time, that work must meet peoples' aspirations for security and voice, for rights and representation, for identity and dignity. That challenge is hard to meet at national level. In the global economy it is harder still.

\section{The process of globalization}

Globalization is widely conceived as a process which is essentially driven by economic and technological forces - increasingly global markets for goods and capital, new communications technologies which reduce the natural barriers of time and space (World Commission report, p.24). As such it is often seen as the motor of economic growth. $^{2}$

\footnotetext{
1 This paper draws on the Report of the World Commission on the Social Dimension of Globalization, A fair globalization: Creating opportunities for all, Geneva; ILO (February 2004), and on background research undertaken for the Commission, including work by Susan Hayter, Rolph van der Hoeven (who also provided valuable comments) and Eddy Lee. However, this is a personal view of the author, which does not necessarily reflect the position of the Commission or its members, nor of the ILO.

${ }^{2}$ For a recent argument along these lines, see Wolf (2004).
} 
It is therefore striking that globalization, at least as a phenomenon of recent decades, has not been associated with higher growth of the global economy. As the World Commission's report points out, the impact of globalization on growth and development has at best been ambiguous. World GDP growth has been declining as globalization has accelerated, as graph 1 shows. ${ }^{3}$ Moreover, the considerable volatility of growth is apparent from the graph. Of course one cannot demonstrate that growth would not have declined further in the absence of globalization, but as the World Commission report points out "at the very least this outcome is at variance with the more optimistic predictions on the growth-enhancing impact of globalization” (p.35). This is all the more notable since positive growth impacts are widely expected both from the liberalization of international trade and capital markets and from the surge of new developments in information technology which underpin the present pattern of globalization.

\section{Graph 1: World GDP per capita growth, 1961-2003 \\ (annual change in per cent)}

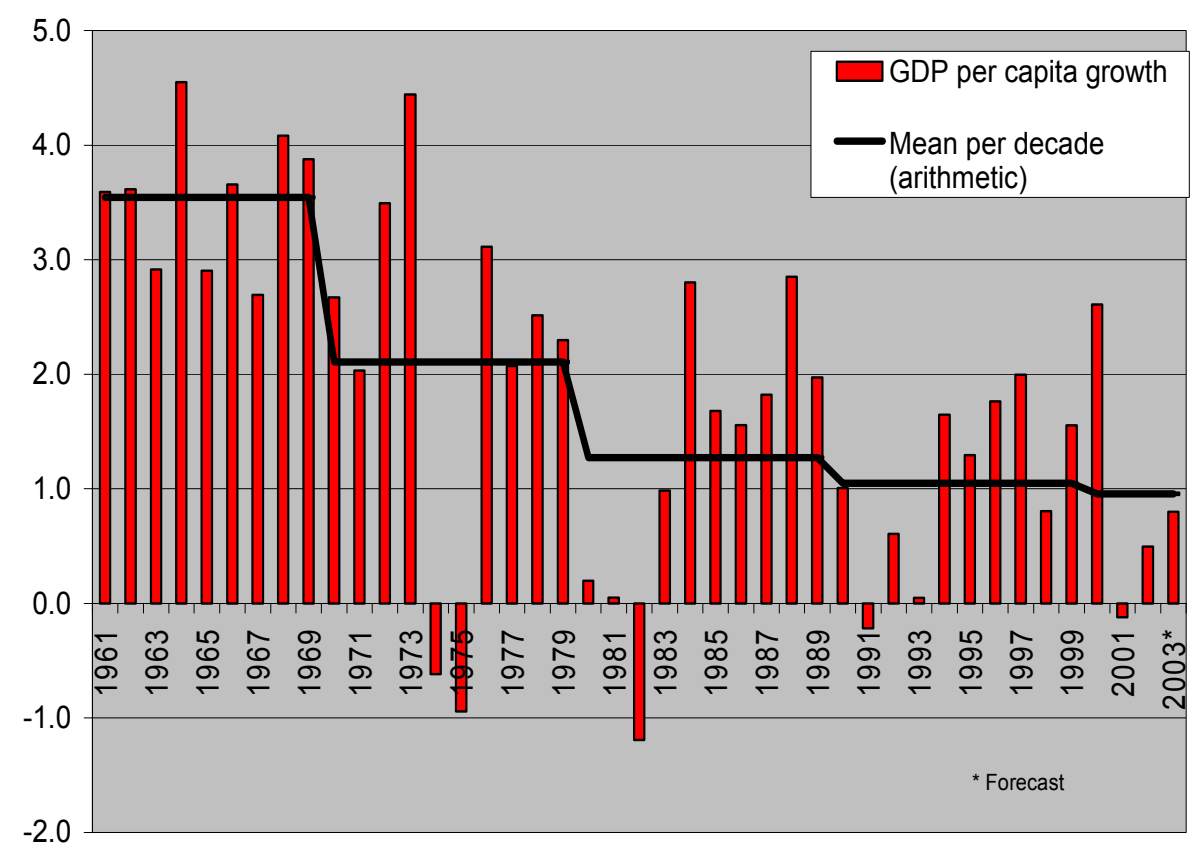

Source: World Commission Report

Nor has globalization led to convergence between countries in incomes and factor remunerations, contrary to simplistic models of the international economy (for a critique see e.g. Ocampo, 2002). In reality, the gap between richest and poorest countries has widened. The ratio between the 20 richest and 20 poorest countries in GDP per capita rose from 53 in 1960-62 to 121 in 2000-02 (World Commission report, figure 11). On the whole the dynamics of international integration reward those economies where there is already a concentration of capital and skills, strengthened by their capacity to invest in

\footnotetext{
${ }^{3}$ Since the graph shows GDP per capita, and the rate of population growth has been declining, the decline in GDP growth overall has been greater still. Data for 2004 show some recovery of global output growth, but it would have to be sustained for several years to significantly change the picture.
} 
education, and in research and development, which increases their comparative advantage further. So there is a built in tendency to polarization, reinforced by highly concentrated flows of FDI in global production systems. The result is vast differences between countries in opportunities and in the ability to take advantage of those opportunities.

It is true that some countries have succeeded in traversing, to a greater or lesser degree, the gap between developing and developed. Higher rates of economic growth and poverty reduction in East Asia, notably in China, and to a lesser extent in India and a few countries in other parts of the world, cannot only be attributed to globalization, for many other factors were involved, but successful exploitation of global economic opportunities played an important role. At the same time, these countries have used a variety of devices to protect themselves from competitive forces in the global market (see e.g. Rodrik, 2001; Amsden, 2001) while they increased national capacity. Opening up to the global economy without that capacity is a recipe for deindustrialization, as uncompetitive enterprises fail. Meanwhile, in other parts of the world, notably but not exclusively in Africa, growth has been low and poverty increasing.

But it is hard to generalize from these patterns. There are always exceptions to any trend, suggesting that national and regional structures, institutions, capabilities and policies have a major effect. As in all walks of life the new opportunities are disproportionately captured by those with the capabilities, the determination, the resources and the power to do so. Globalization may well be a positive sum game, but that does not mean that all benefit.

The impact of globalization on work and employment illustrates this well. Successful integration in the global economy can lead to increased employment and rising wages. This was the experience of several East and Southeast Asian countries for extended periods up until the financial crisis of the late 1990s. Chile, Ireland and a number of other small, open economies have likewise experienced periods of sustained employment creation. ${ }^{4}$ At the same time, there are a number of ways in which different aspects of globalization can have adverse effects on the labour market.

First, increased economic and financial volatility, associated with the liberalization of international financial markets, has led to more frequent economic crises, with significant consequences for unemployment (Stiglitz, 2002). A ratchet effect can often be observed, in which unemployment does not fall to pre-crisis levels in the recovery (World Commission report, figure 14). Thus in Latin America, open unemployment ratcheted up during the crises of the 1980s and 1990s to reach historic highs of around 10 per cent for the continent as a whole in 2003 (ILO, 2003).

Second, increased competitive pressures in global markets are widely observed to result in erosion of labour protection or informalization of employment relationships. There are frequent reports of restrictions on trade union rights in export processing zones, for example ${ }^{5}$.Workers who are essentially organized at the national level find their bargaining power limited by the ability of enterprises to readily shift production to lower cost countries.

Third, increased tax competition results in lower taxation of high personal incomes (Torres, 2001) and of corporate profits (KPMG, Corporate Tax Rate Survey, 2003, quoted in the World Commission Report), and the liberalization of trade reduces government revenues from tariffs - all of which is likely to reduce the resources available for government social expenditure, and to put pressure on public sector employment.

\footnotetext{
${ }^{4}$ For the case of Chile, see ILO (1998).

${ }^{5}$ For instance, see ILO, Employment and Social Policy Committee (2002).
} 
Fourth, globalization leads to increased restructuring of production, involving relocation and outsourcing, substantial job loss in some countries and gains in others, and labour market instability. While the adverse impact in industrialized countries is given most coverage by the global media, developing countries are not always beneficiaries. For instance, changes in the rules of the international trading system for textiles and garments are likely to lead to substantial job losses in Bangladesh and some other low and medium income countries, to China's advantage. There is an important gender dimension, since women's jobs seem more vulnerable to these swings. More generally, the drive for productivity growth in global production systems seems to result in relatively low levels of formal employment creation, intensifying the parallel growth of a large informal economy.

Fifth, as noted above, the capability of countries to take advantage of global market opportunities is highly polarized, so that in many countries there is little opportunity for employment creation though participation in global markets. On the contrary, low productivity national industries in developing countries may collapse when exposed to international competition, enterprises close and jobs are lost. On the other hand, some countries have been able to take advantage of a reservoir of skills and entrepreneurial capabilities to generate substantial employment growth - the software industry in India is a good example.

All this implies that globalization can and often does increase deficits in both the quantity and quality of employment. This is not inevitable. There are countries which have successfully used the space for national policy and taken advantage of global opportunities. But insofar as globalization is identified with increasingly liberalized global markets, there is a tendency to polarization rather than convergence, and the simultaneous creation of large groups of both winners and losers, both within and between countries.

\section{The wider context}

Globalization is not only about increased international trade and capital flows. These macroeconomic changes are themselves associated with changes in the organization of production at the global level (Hayter, 2004). Global production systems, involving chains of interdependent enterprises contributing to different stages of the production process, are not new, but improved technology, better communications and the liberalization of markets have boosted them enormously. A relatively small number of multinational firms manage these processes, in some cases all the way from the production of raw materials to the final consumer. A substantial fraction of international trade in manufactures now takes place within firms, and in many sectors the success or failure of individual countries to take advantage of global opportunities depends on their ability to integrate global supply chains. Initially confined to certain manufacturing sectors (electronics, auto manufacture, garments), this trend is now extending to some services too.

So globalization is more than the growth of efficient global markets. New institutions are developing, both economic - firms, brands and markets - and social, in the sense of crossborder organization and interaction. There are many possible patterns, depending on the underlying forces and interests and the institutions and regulatory frameworks which are put in place. The shape and impact of globalization is not predefined. 
This is particularly obvious once we step beyond the economic domain. The present model of globalization leads to greater flows of information and exchanges between cultures and a greater global sharing of both goods and bads. It includes cultural changes which range from the penetration of Bollywood and Hollywood to global sporting events or world music. The availability of new consumer goods - the mobile phone, for example - leads to changes in social patterns. Dress codes change. Cheap communications mean that every country's diaspora is in touch with what happens at home, and also acts as a channel for ideas and behaviours.

What is happening might reasonably be seen as the first stage in the constitution of a global society. That might result from the spread of similar technologies, both in production and in daily life. Or it might reflect an increasingly common pattern of consumption or social habits, especially among a transnational elite. It could also come from an increasing consciousness of people that they belong to a single world, as communications improve. It might be fostered by the global presence of particular powerful actors - nations, corporations. International organizations, both intergovernmental and private, can also play an important role. Whatever the starting point, with increased interconnection we can plausibly argue that the reach of global society will extend further.

But only fragments of a global society can be observed today. The majority of people rarely if ever leave the country where they were born. Large numbers of countries are on the margins of the global market, too small to interest the important players. For them, globalization is more a source of disruption and of dispossession than of opportunity. In most countries, the main focus of human interest and of government policy remains national. Throughout the world, the middle classes and the rich are vastly more globalized than the poor, the young more globalized than the old. The benefits of globalization reach only a part of each country's population, and in the poorest countries only a small fraction.

Nevertheless, as education levels rise, markets are liberalized, and telecommunications spread, the level of penetration of globalization is rising, and the process looks set to continue. The lives of people increasingly depend on factors outside national borders. And as a result, some of the questions that have been or are faced in the construction of national societies are increasingly relevant for globalization too:

- What are the principles and values that should guide this process?

- $\quad$ Can a common interest be identified? How can it be promoted and protected?

- How can inequalities and injustices be addressed and resolved?

- How can the differing goals of citizens, both men and women, from different communities and parts of the world, be asserted, articulated and conflicts resolved?

- How can the different sources of power (economic, social, political, religious, intellectual, military) be channeled and restrained?

Within nations, the answers to these questions can be found to a greater or lesser degree in institutions of political representation and justice, in the formulation of public policy, the regulation of the behaviour of private actors and the definition and protection of rights. This involves not only legislative action and enforcement by the State, but also collective action by different groups to promote goals and defend interests. The priorities and responses vary enormously with culture and historical context. The degree of success of course varies from country to country, but in all nations such issues condition political action. 
Many of these national mechanisms have no real counterpart at the global level. Whereas the public interest is in principle represented by the State at the national level, at the global level it will for the foreseeable future be represented by a community of independent sovereign States. What is more, the power of those States and their willingness to accept collective responsibility is unevenly distributed, their democratic credentials vary greatly, and their interests often do not coincide. The absence of global central authority, both now and in the foreseeable future, drastically restricts the range of instruments that might be applied, and so the policies that are pursued within States are not necessarily a guide to what may be possible at the global level, because the instruments for their replication are not available at that level. Nevertheless, many of the key questions are the same. The issue is how coordinated action in the interests of all can be achieved, and the approaches and instruments which may promote this.

Globalization also poses questions that lie beyond the normal purview of the nation State. Questions of global peace and security, of climate change, of the global commons, of access to scientific knowledge and technology, of the volatility of the global economy all are international by nature. Such global public goods call for global policy interventions that are qualitatively different from those applied at the national level. Multilateral institutions already exist, essentially in the United Nations system, to pursue these issues, but their capacity to act remains limited.

In the absence of an overall public policy framework for pursuing the common interest at the global level, we must consider the objectives and roles of all the different actors who influence economic and social outcomes at this level. Any attempt to manage globalization must first understand the forces behind it. It can be argued that in previous globalizations, notably the imperial expansions of the sixteenth and nineteenth centuries, there was a plan, an active and coordinated policy to achieve a particular goal of global power. Is that true today? Many argue that the driving force behind the present pattern of globalization is the neo-liberal economic model, with its accompanying domination of production and markets by a small number of States and large corporations. This is certainly the basis for the critique of globalization by many civil society movements.

Nevertheless, even if this is part of the story, there are many other factors involved. Communications technology plays a role in its own right, as do increasingly outward looking political systems in many parts of the world, involving a greater willingness by States to accept interdependence. There are opportunities in global markets for both producers and consumers, and many actors engaged in taking advantage of them. So the current process of globalization reflects the multiple objectives of many actors. Within it, as in any human activity, there are centres of power and influence. There is a political economy of globalization that it would be naïve to ignore. But there is also much space for intervention. It is not utopian to try to design a framework for the governance of globalization (Nayyar, 2002), and the report of the World Commission addresses precisely this issue.

\section{The actors of globalization}

The present pattern of globalization, then, reflects the behaviour and interaction of many individual and collective actors, both national and international. Any effort at developing global social policy has to understand the motivations and capabilities of these actors, and the ways in which they can and do contribute to social goals, either indirectly, as the byproduct of the pursuit of private interests in global markets, or directly through public policy actions. This section therefore considers the roles, responsibilities and contributions of some of the key actors. 


\section{The State}

The obvious starting point is to consider the role in globalization of the nation-State. Although market liberalization often carries with it an anti-State ideology, and globalization has reduced the power of many instruments of state action in the economic field, national governments still retain, to varying degrees, the capability to promote and articulate the values and goals of people in the process of globalization, including in social domains such as health, security, labour and education, all of them essential foundations for a market economy, whether national or global.

There are two dimensions to the State's role in relation to the social dimension of globalization. The first lies within countries. Domestic policies have a great deal of influence over whether countries benefit from globalization, and the nature and distribution of those benefits. Many States engage in strategic investment to take advantage of globalization, notably investment in education, skills and capabilities, investment in key productive sectors, or investment in research, science and technology aimed at generating a longer-term comparative advantage. Of course, the extent to which States can take advantage of this potential depends on their resources and capabilities, which in many countries are extremely limited. A second aspect concerns the ability of States to control or regulate the actions of its citizens or enterprises beyond its borders. Thus the border-free Internet has in the end turned out to be responsive to at least a degree of state regulation (because internet service providers have to be located somewhere), and the legal frameworks which have developed at national level retain a degree of effectiveness even in the global economy, for ultimately even global enterprises must operate within countries.

The second lies in coordination between countries. The interdependence of States implies that the gains from coordination are large. Many international pacts and conventions concern agreements between States to either apply similar domestic policies, thereby avoiding socially undesirable competition, to operate under a common set of rules, to extend reciprocal advantages or - like OPEC, for example - to act as a cartel in global markets. The most developed form of this coordination presently lies in mechanisms such as trade rules or international labour standards, but a much wider agenda is possible. In particular, the development of better international frameworks for the fair, efficient and predictable regulation of markets for capital, goods and services would be in the general interest.

There are in practice many difficulties in achieving coordinated action on social policies between States. They include problems of monitoring and enforcement, democratic deficits in the reaching of agreements and the inevitable tendency for power relations to trump real needs. International coordination requires States to act responsibly in respecting the legitimate goals and rights of other countries, which is of course far from the case since domestic agendas dominate. The policy agenda is, in practice, dominated by the interests of the most powerful states.

\section{Enterprises}

Given the limits to public action and regulation in the global economy, it seems inevitable that enterprise behaviour, especially the behaviour of multinational enterprises in manufacturing, trade and finance, will play an important role in achieving social objectives. Enterprises are carriers for social goals and values. They are social organizations as well as economic ones, and this is reflected in their organization and functioning, and the extent to which they internalize social objectives. That can refer to the treatment of workers within firms, the treatment of clients and customers, as well as the wider notion of corporate citizenship and social responsibility. But there is no single global model of corporate culture. For example, Hutton (2002) argues that there is a greater 
willingness for enterprises to accept socially responsible regulation and taxation in the continental European social environment than in an "Anglo-Saxon" laissez-faire model, and that this can be traced to the different historical origins of the two models. In other regions of the world the predominant pattern of enterprise responsibility and obligation is different again.

There are a number of routes into this issue.

The first, and perhaps ultimately the most powerful, lies in the synergy between social and economic goals. The contribution of social policies to the stability and sustainability of the global economy, and indeed their direct contribution to productivity at the enterprise level, is a strong incentive for enterprise commitment to those objectives. The pursuit of social objectives by business is a regular subject of discussion at the annual World Economic Forum in Davos, Switzerland, where there is widespread recognition of the longer-term value added of such activities for corporate legitimacy, productivity, image and market expansion, and so their contribution to the business objectives themselves.

The second lies in the development of international frameworks and codes of conduct to guide the behaviour of firms in the global economy, such as the ILO Tripartite Declaration of Principles Concerning Multinational Enterprises and Social Policy (1977, revised 2000), or the OECD Guidelines for Multinational Enterprises (OECD, 2000). These are non-binding guidelines; attempts to develop frameworks which would impose obligations meet considerable resistance, as has been the case in the on-going work of the UN SubCommission on the promotion and protection of human rights to develop proposed norms for the responsibilities of transnational firms.

The third lies in the more general practice of voluntary corporate social responsibility. This embraces a wide range of voluntary actions and guiding principles for individual firms, which may include respect for human rights and labour or environmental standards, devoting a proportion of investment to specific national priorities, or participating in local projects for community development, education and other socially desirable ends. It includes international initiatives, such as the UN Secretary General's Global Compact, to which 1800 multinational firms have now declared their commitment, which involves agreement by the enterprises concerned to respect ten basic principles concerned with human and labour rights, the environment and ethical standards. The whole subject of CSR bristles with difficulties, of course, such as the problems of independent monitoring, and ensuring respect for CSR through long and complex global supply chains. When faced with economic difficulties, the social activities are liable to be sacrificed first. Moreover, insofar as social responsibility has a cost, there is a constant problem of free riding. Nevertheless this is an area which is attracting rapidly expanding interest.

The fourth lies in new institutional forms for private economic activity. Social entrepreneurship, which is explicitly aimed at social goals, is growing. Cooperatives provide a long-standing collective institutional framework, which has been widely successful in promoting community as well as economic objectives. Non-market forms of economic organization are deeply embedded in many societies. The importance of these options lies in their capacity to reinforce local action in the face of globalization. But they are not very visible at the international level as yet.

\section{Organized labour}

In the construction of the social agendas of most industrialized and many developing countries in the twentieth century, organized labour played an important role, through its ability to negotiate social gains at the enterprise or sector level, though national pacts and agreements, and through advocacy and mobilization. 
Globalization has certainly undermined some of the capability of the trade union movement to promote national social agendas, and this is surely one of the causes of declining membership - along with the decline of traditional industries with high levels of unionization. The informalization of production in many parts of the world has been a further obstacle, and while the organization of workers in the informal economy is on the trade union agenda in many parts of the world, progress has been slow. Women are often poorly unionized. There is therefore a constant challenge of representativity.

In recent years there has been a growth in cross-border trade union organization, and attempts in some sectors to engage in regional or global social dialogue over wages and working conditions. The International Confederation of Free Trade Unions (ICFTU), the dominant global federation, actively promotes a social agenda in major negotiating forums such as the World Trade Organization, and pursues a dialogue with the World Bank and the IMF. The main difficulty which cross-border trade union activity faces is finding someone to negotiate with. Willingness among multinational enterprises to engage in global social dialogue is very limited at present, and responsibility is distributed through networks of suppliers, making coordinated action difficult. The interests of workers in different parts of the world are not necessarily coincident - indeed, globalization can be said to have increased competition not only between firms but also between workers. In some sectors, such as the maritime sector, global social dialogue has made progress, and there have also been a number of framework agreements negotiated between global union federations and some multinationals. But these cover only a tiny fraction of the global economy. Nevertheless, cross-border social dialogue between representative organizations of workers and employers seems likely to eventually become an important force to promote social goals in global economic activity.

\section{Civil society}

A wide variety of civil society organizations are active at the international level, promoting particular ideas and creeds, seeking alternatives to the logic of the market economy, advocating alternative forms of local development, promoting social entrepreneurship, or offering resistance to economic and political hegemony. If we include world religions under this heading, as we should for they are active in all these fields, the scope is wider still. Organizations of civil society are a powerful source of ideas and debate, and effective mobilizers of minority groups and specific interests. The influence of these organizations makes them an essential part of any dialogue on globalization.

The major difficulties faced by civil society include its heterogeneity, lack of organization and often lack of representativeness. Elected politicians often question their democratic credentials. Global civil society speaks with many voices, and so does not provide a coherent policy vision, although this diversity is also a source of strength. Civil society organizations are viewed in some countries as externally directed attempts to manipulate national policies, and certainly many represent and are funded by particular vested interests.

Nevertheless, there are many specific domains where civil society organizations are ahead of the curve. Within the framework of the market economy, non-governmental organizations have led the movement to take social criteria into account in consumer and investor choice. Socially responsible investing is now big business. Consumers too are widely willing to pay a premium for goods that are certified free of child labour or based on the payment of a living wage. As in the case of corporate social responsibility, of course, there is no guarantee that the preferences of investors and consumers will coincide with the objectives of the people whose interests are ostensibly being pursued, and problems of monitoring and feedback remain. But this is a good example of how civil society has changed the terms of the debate. Major civil society organizations are active in 
monitoring how far governments, enterprises and other organizations live up to their commitments, for instance through social audits, and so also make important contributions to ensuring accountability. They are also important forces for gender equality and environmental responsibility.

\section{The media}

The media play a central role in multiplying the impact of globalization. The selection of news and information influences perceptions of globalization, drawing attention both to the opportunities and to the adverse impacts. This can be a vehicle for the dominant global culture, legitimizing lifestyles and providing models. The private media are also the battleground for audience between large corporations seeking advertising revenues, so that the type of information that circulates is intertwined with the mass consumer market. There is high concentration of ownership in the global media, with obvious implications for diversity. Where anti-democratic governments retain control, the media are explicitly used as instruments of propaganda.

So the media constitute an important actor, both enabling and shaping globalization. They may promote social goals - injustice may be newsworthy - or caricature them, or simply ignore them except when disaster strikes. But attempts to regulate and orient the media are widely seen as delivering solutions that are worse than the problem. Attempts to promote a "new world information order" in the 1980s were an outright failure. Some elements of corporate social responsibility can and do apply to the media, of course, so voluntary selfregulation has a role. New forms of global information flow through the Internet have also widened choices, and civil society is playing an increasingly active role to create alternatives. In fact, a decentralized information network may ultimately prove to be an important part of the architecture of a future global society, as Manuel Castells in particular has suggested ${ }^{6}$. But such decentralized networks run counter to the prevailing form of economic organization, and the extent to which they can be multiplied is uncertain.

\section{The multilateral system}

The intergovernmental organizations of the United Nations family presently provide the main institutional framework for global action. The UN retains considerable legitimacy and moral authority, and has a presence in the key domains of global action. Its role in providing global public goods, ranging from peace and security to the elimination of disease, is essential. Regulatory frameworks for trade in goods and services, for capital flows and for international migration are likewise classic public goods, because once in place they benefit all. So the UN system must play a central role in the management of globalization in the common interest.

Different parts of the UN system already have responsibility for major fields of social action - human rights, international labour standards, education, the environment, development more generally - which need to be embedded in the process of globalization. But they face multiple difficulties - lack of resources, insufficient commitment from some important countries, lack of integration between social goals and economic policies. The mechanisms for governance of the global economy are concentrated in the international economic and financial institutions - the IMF, the World Bank and the WTO - and financial and economic goals tend to take precedence over social ones. There is a tendency for the economic and social institutions of the multilateral system to operate in separate

\footnotetext{
${ }^{6}$ See his trilogy on the information age, in particular volume 1 (Castells, 1996).
} 
compartments, so that the negotiations over the trading system, for instance, do not explicitly take social goals into account. This lack of coherence is not only a problem of the institutions themselves, but also reflects different perspectives in the national ministries concerned (that are responsible for the governance of these institutions).

A more effective role for the multilateral system in pursing social goals requires stronger commitment to its action by the States which govern it, and greater coherence of action across its different fields of responsibility. The World Commission report points to these problems, calling for specific initiatives to promote greater coherence. It argues in particular that because of the central role of employment in both economic and social goals, more attention should be paid in global economic management to ways to promote employment and to make decent work a global goal.

\section{Coherence in global action}

All of these different actors have different agendas. The basic question is whether it is possible to bring together these diverse perspectives in such a way that they all contribute to common policy goals. The governance of globalization, broadly understood, has to be built from diversity in the absence of strong central authority. This is not a trivial task, for it requires that different actors playing different roles acknowledge a common responsibility. How can coordination and coherence be promoted?

The World Commission provides no blueprint, but it does highlight three areas which could help - the development of a common ethical framework; social dialogue as a way of building consensus around policies and actions; and the reinforcement of international institutions.

\section{An ethical framework}

Shared values are an essential foundation for governance, and many global and regional declarations and manifestos try to map them out. The UN Millennium Declaration declares the core values to be freedom, equality, solidarity, tolerance, respect for nature and shared responsibility. Its ethical framework incorporates goals such as peace and security, the protection of the vulnerable and respect for a range of internationally recognized human rights.

The proposed new European constitution too starts by declaring its values: human dignity, liberty, democracy, equality, the rule of law and respect for human rights. In the text further explicit value statements can be found. They are expressed in the rights attached to European citizenship, for instance (which include cultural rights such as use of one's own language, and freedom of movement), as well as the absence of discrimination on national grounds (European Convention, 2003).

The New Partnership for Africa's Development (NEPAD) is likewise built on many expressed values: peace and security; democracy and human rights; people-centred development; harmony between humanity and nature; self-reliance; accountable government; promoting the role of women.

At least at the level of rhetoric, many of the values expressed in such international declarations have very widespread support. But scepticism is also widespread. The notion of "universal values" has frequently been misused to promote particular interests. Values are often expressed so vaguely that they are of little practical help. And they are inevitably embedded in the perspectives, beliefs and history of cultures, religions and societies. Even 
when values are shared, priorities vary, and responsibility may not be acknowledged. Action often lags behind words.

Nevertheless a pragmatic approach is possible, around principles and values to which there is widespread adherence. Following Amartya Sen (1999), the primacy of democratic choice is surely fundamental, if it is interpreted as a globalization chosen by people, which respects their own goals ${ }^{7}$. The World Commission highlighted respect for human rights and human dignity; respect for diversity; fairness; solidarity; gender equality and respect for nature. It also identified the core values for "an open and effective market economy", including honesty, responsibility, and transparency. Taken together, these could provide the foundation for the democratic governance of globalization.

The emphasis of the World Commission report on fairness is particularly worth noting. While to some degree fairness is in the eye of the beholder, the sense that the present model of globalization is unfair is an important mobilizing force. For instance, widespread recognition of the unfairness of global trade rules has influenced the Doha round of trade negotiations which are presently under way. The wide inequalities among countries and people in access to the benefits of globalization are also readily described as unfair, and the goal of a fair globalization is one with which most people can identify.

\section{Building consensus through dialogue}

There is also, in the World Commission report, a strong emphasis on inclusive dialogue and debate as a means to build common solutions. This is the method of work of the ILO itself, which has successfully applied tripartite dialogue (among governments, workers and employers) to reach agreement on many international instruments. The Commission extended this in its own work to include other groups - parliamentarians and politicians, civil society and academia - and regarded its success in nevertheless reaching a common position as an important demonstration of the power of the method.

A process of dialogue is most effective if built around a positive sum game, in which the power of the different parties is not too unbalanced. For many aspects of global social policy this condition is certainly not met. But there are also important domains where the common interest is strong, and a more general sense that beyond a certain point, injustice and inequality threaten the stability of the path of globalization itself. If there is convergence on the ethical framework the sense of a common interest is reinforced. So the Commission's proposals for multistakeholder dialogues on issues such as social protection, the cross-border movement of people or corporate social responsibility may be productive. If as a result of such dialogues groups with different starting points and interests reach agreement on what needs to be done, the likelihood of implementation is distinctly greater.

Attempts to build more formal structures of negotiation on social issues at the global level face greater problems, partly because of the disparity in power among the different parties concerned - among countries, or between global corporations and other actors. For instance, as noted above, while some global framework agreements have been negotiated between multinationals and union federations, they remain the exception. Yet it is probably in such situations, where there is ultimately a common interest of all actors in the production system, that most progress can be expected in the future.

\footnotetext{
${ }^{7}$ One corollary is that there must also be the freedom to choose not to participate in some aspects of globalization.
} 


\section{International institutions}

As noted above, the organizations of the multilateral system, essentially the United Nations family, along with the existing body of international law, provide the principal framework for coordination among different global actors. Clearly the development of this framework, both legal and institutional, is a sine qua non for the promotion of common social policy goals. Multilateralism, as the World Commission says, is both indispensable and inevitable.

But the multilateral system faces difficult problems. There are political challenges to its authority; and constant pressures on its resources. And for it to provide an effective framework to bring together different actors, it must itself operate in a coherent fashion. As the World Commission points out, in some respects, notably with respect to the coherence between economic and social policy making, there is a great deal of room for improvement. The legitimacy of the multilateral system as a framework for social policy development would also be enhanced if there were stronger mechanisms of accountability to people, both through more democratic process and through external oversight.

Beyond the formal multilateral system, a host of more or less structured frameworks, ranging from the G-8 to the World Social Forum, provide a diversity of contexts and mechanisms for global policy development. But as these two examples illustrate, they are often partial or unbalanced in their representation. It is in the reinforcement of the UN system that most scope for progress lies.

\section{The globalization policy agenda and development}

Probably the greatest challenge facing the actors of globalization is the enormous and persistent disparity across countries in levels of development, and across people in levels of income. If globalization to deliver effectively on social goals, it has to be a force for development. All actors have an interest here, for in the long run it is the stability of the global economic system which is at stake.

The implication is that developing countries must have the means to take advantage of the global economy. They need to be able to create and use comparative advantage; their resources and activities must be fairly rewarded; their disadvantages compensated; their exclusion regarded as a global problem, and not only a local one. They must have access to the technologies on which high productivity production systems are built, and to the knowledge which global communications makes possible. Their participation in the global economy must be consistent with their own cultural contexts and national priorities.

The issues lie partly in the international arena: in fair rules for trade; in international financial systems which offer medium term stability for capital markets; in agreements on technology access and intellectual property which take into account the needs and disadvantages of low income countries. They also lie in strengthening the voice of developing countries in the international negotiations on these issues.

But there is also a substantial space for national and regional policies to take advantage of globalization, and that space has to be legitimized and fully exploited. Institutional and policy action is required in at least three major respects. 
The first lies in the building up of the economic capacities of national actors - enterprises, workers, governments. That means action on skills, technological capability, infrastructure, or more generally competitiveness. That is the way that comparative advantage is created. It is basically a question of strategic choices in both human and physical investment. In this respect, large countries such as India and China are relatively advantaged, since often a critical mass of resources is required to reach a capacity threshold.

The second concerns the strengthening of national institutions. That means fair rules of the game, legal frameworks which permit enterprises to develop and grow, capital markets which support productive investment, labour markets which provide opportunity while protecting rights, mechanisms to correct market failures and improve the distribution of benefits, an effective system to raise public resources. The key actors of national economies need to be strengthened, differing interests brought into dialogue around shared values, and systems of representation and protection institutionalized.

And the third lies in the mechanisms by which the benefits of globalization are transmitted to people. And of these, the most important is work and employment. Policies to ensure that globalization is translated into employment are critical. Without large scale creation of employment, the benefits of globalization will tend to remain concentrated. And because of the importance of work in achieving a wide range of social and economic objectives, the goal must be work and employment that meets social standards and supports the broad aspirations of people - decent work.

A focus on work illustrates a more general principle: a fairer globalization needs to be built on a better integration of economic and social policies. Market economies need institutions to generate stability, security, trust and legitimacy, and a commitment to longer-term goals. Some of these institutions concern the transparency and honesty of the market process itself. Others concern its social underpinnings. Jacques Delors said, speaking of Europe but his argument applies to the world as a whole - "The creation of a vast economic area, based on the market and business cooperation, is inconceivable - I would say unattainable - without some harmonization of social legislation" (quoted in Hutton, 2002). The question is one of developing the policies, rules and mechanisms by which economic and social goals can be coordinated in the global economy, whether through social legislation or through the coordinated actions of a range of actors, in the common interest.

Obviously constructing a fairer global society is a project for the $21^{\text {st }}$ century as a whole. European integration is still unfinished business after more than half a century of effort. And it required two devastating wars before progress towards a common European approach became possible. A similar response is not yet forthcoming at the global level, despite famines, terrorism, exclusion, the spread of HIV/AIDS, global warming, the persistence of extreme poverty and other global dangers. Yet in the medium term it is in the interests of the winners from globalization to build the institutions that would share the benefits more widely. A fairer globalization would be an important foundation for a more secure world. 


\section{References}

Amsden, Alice, 2001: The rise of "The Rest": Challenges to the West from late-industrializing economies. Oxford University Press.

Castells, Manuel, 1996: The rise of the network society. London, Blackwell.

De Soto, Hernando, 2000: The mystery of capital: Why capitalism triumphs in the West and fails everywhere else. New York, Basic Books.

European Convention, 2003: Draft treaty establishing a Constitution for Europe. CONV 850/03. Brussels, July.

Hayter, Susan, 2004: "The social dimension of global production systems: A review of the issues", Policy Integration Department Working Paper 25. Geneva, ILO

Henderson, Hazel, 1999: Beyond globalization: Shaping a sustainable global economy. West Hartford, Connecticut, Kumarian Press.

Hutton, Will, 2002: The world we're in. London, Little and Brown.

International Labour Office, 1998: Chile: Crecimiento, empleo y el desafío de la justicia social. Santiago de Chile, ILO.

ILO, 2000: Tripartite Declaration of Principles Concerning Multinational Enterprises and Social Policy. Geneva, 1977, revised 2000.

ILO, 2003: Panorama Laboral 2003: América Latina y el Caribe. Lima, ILO.

ILO, Employment and Social Policy Committee, 2002: "Employment and social policy in respect of export processing zones (EPZs)”, GB.285/ESP/5. Geneva, November 2002.

Kaul, Inge; Isabelle Grunberg; Marc Stern, 1999: Global public goods. Oxford University Press.

NEPAD, 2001: The New Partnership for Africa’s Development. Abuja, October.

Ocampo, José-Antonio, 2002: “Globalization and development”, paper presented to the International seminar on "New international trends for economic development". Rio de Janeiro, BNDES, September.

Nayyar, Deepak, 2002: Governing globalization: Issues and institutions. Oxford University Press.

OECD, 2000: Guidelines for multinational enterprises. Paris.

Polanyi, Karl, 1944: The great transformation. Boston, Beacon Press (reprinted 1957).

Rodrik, Dani, 2001: The global governance of trade as if development really mattered. New York, UNDP.

Sen, Amartya, 1999: Development as freedom. Oxford University Press.

Stiglitz, Joseph, 2002: Globalization and its discontents. London, Allan Lane. 
Torres, Raymond, 2001: Towards a socially sustainable world economy: An analysis of the social pillars of globalization. Geneva, ILO.

United Nations, 2000: Millennium Declaration. New York.

Wolf, Martin, 2004: Why globalization works. New Haven, Yale University Press.

World Commission on the Social Dimension of Globalization, 2004: A fair globalization: Creating opportunities for all. Geneva, ILO. 


\section{Policy Integration Department Working Papers}

No. 1 ILO activities on the social dimension of globalization: Synthesis report

No. 2 Measuring decent work with statistical indicators

Richard Anker, Igor Chernyshev, Philippe Egger, Farhad Mehran and Joseph Ritter

No. 3 Globalization and decent work: Options for Panama Philippe Egger

No. 4 Globalización y trabajo decente: Opciones para Panamá Philippe Egger

No. 5 Indicators of social dialogue: Concepts and measurements Lane Kenworthy and Bernhard Kittel

No. 6 Assessing the impact of the attacks of 11 September 2001 on women's employment in the United States

Gertrude Schaffner Goldberg and Helen Lachs Ginsburg

No. 7 Decent work and the informal economy in Central America Juan Diego Trejos Solórzano and Miguel Del Cid

No. 8 Poverty initiatives in the ILO: A review of past and present approaches Pat Holden and Dagmar Walter

No. 9 Whither the International Standard Classification of Occupations (ISCO-88)? Debbie Budlender

No. 10 Improving occupational classifications as tools for describing labour markets: A summary of recent national experiences

Debbie Budlender

No. 11 Recent developments in China's labour economy Thomas G. Rawski

No. 12 The Impact of economic liberalization on employment and wages in India Sonia Bhalotra

No. 13 The impact of trade liberalization upon inequality in developing countries Donald J. Robbins

No. 14 The impact of liberalization and globalization on income inequality in developing and transitional economies Giovanni Andrea Cornia

No. 15 The impact of technology transfer on employment and income distribution in developing countries: A survey of theoretical models and empirical studies Mariacristina Piva 


\section{Policy Integration Department Working Papers \\ Prepared by the World Commission on the \\ Social Dimension of Globalization}

No. 16 International finance: Meeting the needs of people in developing countries José Guilherme Almeida dos Reis

No. 17 The gender dimensions of globalization of production Stephanie Barrientos, Naila Kabeer and Naomi Hossain

No. 18 Social exclusion in the context of globalization - Jan Breman

No. 19 Gender and globalization: A macroeconomic perspective Çağatay Nilüfer and Ertük Korkurt

No. 20 Globalization, social exclusion, and work: with special reference to informal employment and gender - Marilyn Carr and Martha Chen

No. 21 Resources for social development - Antony Clunies Ross

No. 22 Does the new international trade regime leave room for industrialization policies in the middle-income countries? - Alisa DiCaprio and Alice Amsden

No. 23 Social dimension of globalization in Latin America: Lessons from Bolivia and Chile, Ivaro García Hurtado

No. 24 The social dimension of globalization: a review of the literature Bernhard Gunter and Rolph van der Hoeven

No. 25 The social dimension of global production systems: A review of the issues, Susan Hayter

No. 26 Reforming global economic and social governance:

a critical review of recent programmatic thinking - Jeremy Heimans

No. 27 Corporate social responsibility: an issues paper - Michael Hopkins

No. 28 Upgrading in global value chains - John Humphrey

No. 29 Implications of globalization and economic restructuring for skills development in Sub-Saharan Africa - Richard K. Johanson

No. 30 The outcome and impact of the main international commissions on development issues Frédéric Lapeyre

No. 31 Globalization and structural adjustment as a development tool - Frédéric Lapeyre

No. 32 Globalization and perceptions of social inequality - Malte Luebker

No. 33 The changing structure of international trade linked to global production systems: what are the policy implications? - William Milberg

No. 34 Corporate social responsibility: an overview of principles and practice,Jill Murray

No. 35 Inclusive development strategy in an era of globalization - Ignacy Sachs

No. 36 Social consequences of the globalization of the media and communication sector: some strategic considerations - Seán Ó. Siochrú

No. 37 Globalization, history and international migration: a view from Latin America Andrés Solimano

No. 38 Towards a different kind of globalization, or how the anti-globalists view the world Gijsbert van Liemt 


\section{Policy Integration Department Working Papers}

No. 39 How do trade union rights affect trade competitiveness? David Kucera and Ritash Sarna

No. 40 Statistics on the employment situation of people with disabilities:

A compendium of national methodologies

ILO Bureau of Statistics in collaboration with the In Focus Programme on Skills, Knowledge and Employability

No. 41 Employment in the informal economy in the Republic of Moldova ILO Bureau of Statistics in collaboration with the Department for Statistics and Sociology of the Republic of Moldova

No. 42 Decent work in a least developed country: A critical assessment of the Ethiopia PRSP Graeme J. Buckley

No. 43 Unemployment and Labour Market Institutions:

The Failure of the Empirical Case for Deregulation

Dean Baker, Andrew Glyn, David Howell and John Schmitt

No. 44 Women's access to occupations with authority, influence and decision-making power: Women as legislators, senior officials and managers around the world Richard Anker.

No. 45 The world of work in the context of economic integration and trade liberalization Daniel Martínez

No. 46 Poverty reduction in Pakistan: The strategic impact of macro and employment policies Moazam Mahmood

No. 47 Trends in Work Stoppages: A Global Perspective L. J. Perry and Patrick J. Wilson

No. 48 Generating decent work for poverty reduction in Cambodia: The voice of workers, employers and the Government Moazam Mahmood

No. 49 The Social Dimension of Regional Integration in ECOWAS René Robert

No. 50 Measuring trade union rights: A country-level indicator constructed from coding violations recorded in textual sources David Kucera

No. 51 Patterns of job quality attributes in European Union Joseph A. Ritter

No. 52 Child Labour, Education and Export Performance

David Kucera and Ritash Sarna 
No. 53 Measuring the informal economy: From employment in the informal sector to informal employment

Ralf Hussmanns

No. 54 Indicators of labour standards: an overview and comparison

Richard N. Block

No. 55 The pattern of globalization and some implications for the pursuit of social goals Gerry Rodgers 